\title{
Analysis of ethylene glycol in animal feed using liquid chromatography electrospray ionization tandem mass spectrometry
}

\author{
Nguyen Thi Hong Ngoc ${ }^{1 *}$, Nguyen Ha Thanh ${ }^{1}$, Bui Cao Tien ${ }^{1}$, \\ Tran Cao Son ${ }^{1}$, Dinh Minh Nhat ${ }^{2}$, Pham Thi Thanh $\mathbf{H a}^{2}$ \\ ${ }^{1}$ National Institute for Food Control, Hanoi, Vietnam \\ ${ }^{2}$ Hanoi University of Pharmacy, Hanoi, Vietnam
}

(Received: 28/10/2021; Accepted: 24/12/2021)

\section{Abstract}

A determination method of ethylene glycol in animal feed by liquid chromatography coupled with electrospray ionization tandem mass spectrometry (LC-ESI-MS/MS) was developed. The analysis was performed with a C18 column $(150 \mathrm{~mm} \times 4.6 \mathrm{~mm}, 3.5 \mu \mathrm{m})$, and a gradient mobile phase of $0.1 \%$ formic acid solution and acetonitrile. Ethylene glycol and surrogate standard (propylene glycol) were extracted by water at room temperature, derivatized with benzoyl chloride in alkaline medium, and analyzed by LC-ESI-MS/MS. The method has high specificity and selectivity with a detection limit of $0.1 \mathrm{mg} / \mathrm{kg}$, linearity range of $1-20 \mu \mathrm{g} / \mathrm{mL}$, repeatability of $3.08-4.41 \%$, and recovery of $91.1-102.0 \%$, which meet AOAC requirements. This method has been applied to analyze some marketed animal feed samples.

Keywords: ethylene glycol, animal feed, LC-ESI-MS/MS.

\section{INTRODUCTION}

In July 2021, National Institute for Food Control received a feed poisoning case that conducted the death of dogs. The suspected cause of death was acute kidney injury which led to kidney failure. The most common substances that could cause acute kidney injury in dogs are ethylene glycol (EG), medications like non-steroidal anti-inflammatory drugs. Since the dogs did not use medications, so EG had been seen as the center of the case.

Ethylene glycol (EG) (ethane-1,2-diol) is a colorless, syrupy liquid, with molecular mass $62 \mathrm{Da}$, freely soluble in water, used as an antifreeze for some manufacturing [1]. Upon ingestion, EG is oxidized to a toxic substance, oxalic acid. In cases, sufficient amounts are fatal if the patients are untreated [2]. Several deaths are recorded annually in the United State [3]. In Vietnam, these cases related to EG have not been reported yet.

There are some analytical methods to determine EG with gas and liquid chromatography. In gas chromatography coupled with flame ionization detector, EG could be analyzed by direct injection [4], but the risk is the misinterpretation of interfering peaks. In liquid chromatography coupled with tandem mass spectrometry, direct analysis has the problem because of the small molecular mass, which leads to the low signal and high detection limit [5], indirect analysis with benzoyl chloride has advanced [6]. According to the Schotten-Baumann reaction, the benzoyl derivatization of ethylene glycol was formed in an alkaline aqueous phase with the presence of an excess of benzoyl chloride (Figure 1). A proton and a chloride ion are formed during the reaction, so addition of a strong base was required to neutralize this acidic proton to drive the equilibrium towards the formation of dibenzoyl glycol derivatives.

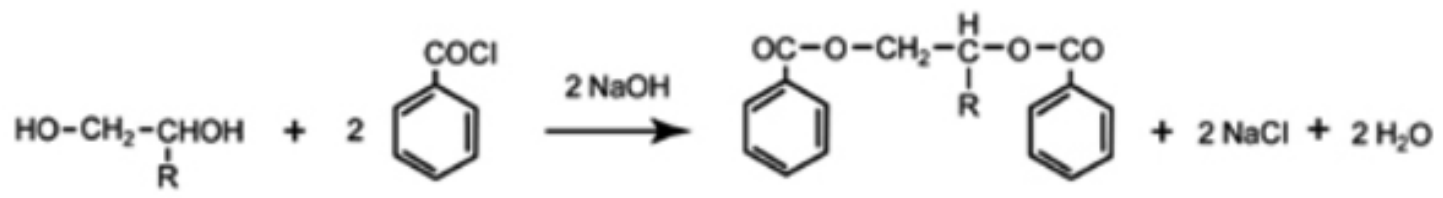

Figure 1. Dibenzoyl derivatization of glycols [6] $(R=H$ : ethylene glycol, $R=C H 3$ : propylene glycol) 
The LC-MS method combined with benzoyl derivatives is known to be the most sensitive method at present, but previous studies have only been performed on plasma, water, soil, cosmetics, and rarely on animal feeds [4-6]. Therefore, this study focused on optimizing an analytical procedure for EG in animal feed samples.

\section{MATERIALS AND METHOD}

\subsection{Chemicals and materials}

Reference standards of ethylene glycol (EG) (>90\%) and surrogate substance propylene glycol (PG) ( $>90 \%$ ) were obtained from the Laboratory of the Government Chemist (United Kingdom). Acetonitrile, formic acid, n-hexane, and sodium hydroxide were purchased from Merck (Germany). Benzoyl chloride was purchased from Sigma-Aldrich (United States).

The sample used for method validation was the animal feed determined to be free of ethylene glycol. Samples for method application $(\mathrm{n}=20)$ included three animal feed types: dry ready-to-feed, wet readyto-feed, ready-to-feed paste. An amount of around $100 \mathrm{~g}$ of each sample was bought from different stores and markets in Hanoi from July to August 2021, include brands from United States, France, Thailand and non-branded products with no information.

\subsection{Equipment}

The analysis was performed on LC-MS/MS system with UPLC and triple quadrupole mass spectrometer 6,500 with electron ionization source (ESI) from SCIEX (United States) and C18 Symmetry column $(4.6 \times 150 \mathrm{~mm}, 3.5 \mu \mathrm{m})$ from Waters (United States). Other types of equipment used in the experiments included analytical balance (Metter Toledo, Switzerland), centrifuge (Sartorius, Germany), vortex mixer (IKA, China), shaker (GFL, Germany), and nitrogen evaporation system.

\subsection{Experiments}

The method was optimized for the derivatization process and validated on dry ready-to-feed sample. Validation tests were conducted according to AOAC guidelines including selectivity, linearity, precision, recovery, the limit of detection (LOD), limit of quantitation (LOQ), and measurement uncertainty [7].

\subsubsection{Standard preparation}

(a). Ethylene glycol/ Propylene glycol stock solution 1,000 $\mu \mathrm{g} / \mathrm{mL}$ : Weigh accurately about $0.1 \mathrm{~g}$ standard to a $100 \mathrm{~mL}$ volumetric flask, add distilled water to the mark, shake regularly. Storage at temperature $2-8^{\circ} \mathrm{C}$, use for three months.

(b). Intermediate ethylene glycol solution $100 \mu \mathrm{g} / \mathrm{mL}$ : Take accurately $1 \mathrm{~mL}$ stock solution to a $10 \mathrm{~mL}$ volume flask, add distilled water to the mark, shake regularly. Storage at temperature $2-8^{\circ} \mathrm{C}$, use for three months.

(c). Intermediate propylene glycol solution $10 \mu \mathrm{g} / \mathrm{mL}$ : Take accurately $1 \mathrm{~mL}$ stock solution to 100 $\mathrm{mL}$ volume flask, add distilled water to the mark, shake regularly. Storage at temperature $2-8^{\circ} \mathrm{C}$, use for three months.

(d). Calibration solution: Use a pipette to take each 10, 20, 50, 100, 200 and $500 \mu \mathrm{L}$ solution (b) and $1 \mathrm{~mL}$ solution (c) to $50 \mathrm{~mL}$ centrifuge tube. Add $30 \mathrm{~mL}$ distilled water, shake regularly. Add $4 \mathrm{~mL}$ Sodium hydroxide and $400 \mu \mathrm{L}$ benzoyl chloride, shake regularly for ten minutes and hold on for ten minutes. Add $10 \mathrm{~mL}$ hexane, shake for 20 minutes. The hexane layer was moved to the other $15 \mathrm{~mL}$ centrifuge tube and taken to dryness with a gentle nitrogen stream. The final extract was made up to $1 \mathrm{~mL}$ by acetonitrile, filtered through $0.2 \mu \mathrm{m}$ membrane to a vial, filtered through $0.2 \mu \mathrm{m}$ membrane to the vial, and analyzed by LC-MS/MS. The calibration curve was accepted with at least three points.

\subsubsection{Sample preparation}

For the sample preparation, we have referred the research of The National Institute for Occupational Safety and Health [1] and also investigated the derivatization conditions. At the time of collection (purchase), the feed was grounded (or minced by an electric mincer), and homogenized thoroughly. 
Weigh accurately about 10.0 g homogenized sample to $50 \mathrm{~mL}$ centrifuge tube. Add $1 \mathrm{~mL}$ solution (c) to sample. Add $15 \mathrm{~mL}$ hexane, shake horizontally for 15 minutes. Centrifuge at the speed of 6,000 rpm for five minutes. Use a Pasteur pipette to remove the hexane layer. Add $15 \mathrm{~mL}$ distilled water and shake regularly. Decant the supernatant to another $50 \mathrm{~mL}$ centrifuge tube. Repeat extraction with other $15 \mathrm{~mL}$ of distilled water. Combine and shake well. Add $4 \mathrm{~mL}$ of $4 \mathrm{M}$ sodium hydroxide solution and $400 \mu \mathrm{L}$ benzoyl chloride, shake regularly for ten minutes, and let still for ten minutes. Benzoyl derivatives were extracted by adding $10 \mathrm{~mL}$ hexane, shaking for 20 minutes. The hexane layer was moved to the other $15 \mathrm{~mL}$ centrifuge tube and taken to dryness with a gentle nitrogen stream. The final extract was made up to $1 \mathrm{~mL}$ by $\mathrm{ACN}$, filter through $0.2 \mu \mathrm{m}$ membrane to a vial.

\subsubsection{LC-MS/MS conditions}

A Symmetry $\mathrm{C}_{18}$ column $(4.6 \times 150 \mathrm{~mm}, 3.5 \mu \mathrm{m})$ was used. The mobile phase system consisted of solution A ( $0.1 \%$ formic acid aqueous solution) and B (ACN). A gradient program started with $10 \% \mathrm{~B}$ to 1.0 minutes, increase to $80 \% \mathrm{~B}$ in the next four minutes, then decrease $10 \%$ in the next 0.5 minutes and hold for 2.5 minutes till the end. The flow rate was set at $0.5 \mathrm{~mL} / \mathrm{min}$.

The triple quadrupole mass spectrometer 6,500 was equipped with an electron ionization source (ESI) source with the following parameters: ESI temperature of $400^{\circ} \mathrm{C}$, the capillary temperature of $350{ }^{\circ} \mathrm{C}$, spray voltage of $4.5 \mathrm{kV}$, sheath gas flow of 35 arbitrary units, the auxiliary gas flow of 32 arbitrary units. The mass spectrometer was operated in the multiple reaction monitoring (MRM). For data collection and analysis, the quantitation was conducted by Analyst software (Sciex). Mass spectrometry conditions and mass fragments are shown in Table 1.

Table 1. Mass spectrometry conditions and mass fragments of analyte and the surrogate

\begin{tabular}{|c|c|c|c|}
\hline Compounds & Precursor ion $(\mathrm{m} / \mathrm{z})$ & Product ions (m/z) & Collusion Energy (V) \\
\hline \multirow[b]{2}{*}{$E G$} & \multirow[b]{2}{*}{271.0} & $149.2^{*}$ & 19 \\
\hline & & 105.2 & 41 \\
\hline \multirow{2}{*}{$P G$} & \multirow{2}{*}{285.0} & $163.0^{*}$ & 10 \\
\hline & & 105.0 & 20 \\
\hline
\end{tabular}

\section{RESULTS AND DISCUSSION}

\subsection{Derivatization conditions}

The amounts of benzoyl chloride and sodium hydroxide concentration used, as well as the reaction time of the experimental, were optimized to maximize the amount of dibenzoyl glycol derivatives (Figure2).

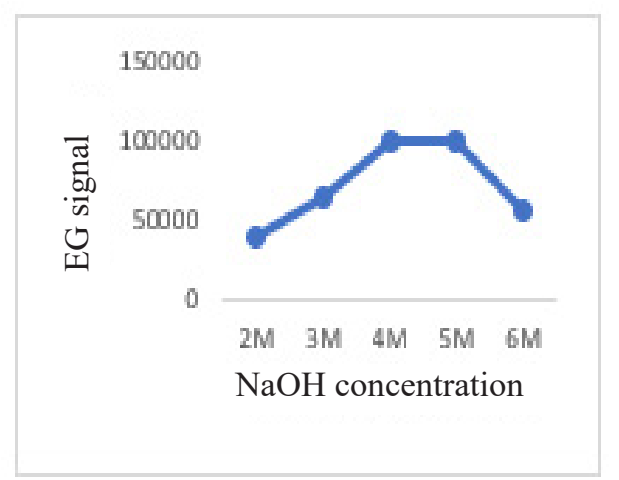

a. Amounts of sodium hydroxide

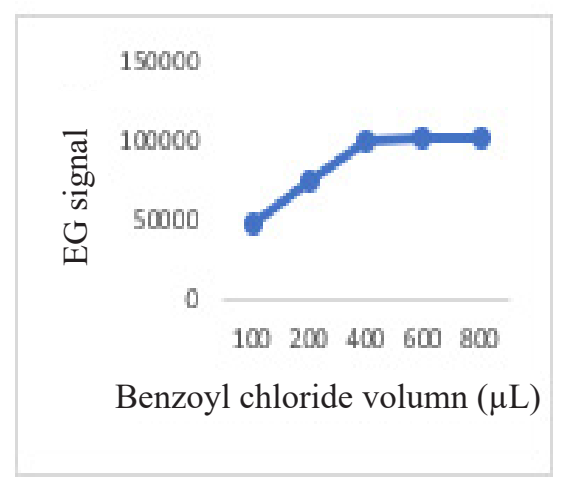

b. Benzoyl chloride volume

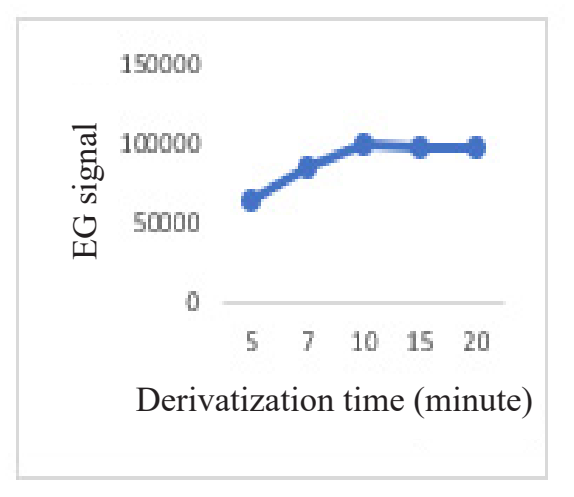

c. Reaction time

Figure 2. Derivatization process optimizing 
The results of the derivatization optimization process showed that using $4 \mathrm{M}$ sodium hydroxide solution and $400 \mu \mathrm{L}$ of benzoyl chloride in ten minutes, the dibenzoyl derivatization rate of ethylene glycol formed would be the highest. This result has no significant deviation from previous studies [6].

\subsection{Method validation}

\subsubsection{Specificity}

The result showed that both the analyte and the internal standard have an identification point (IP) score of four which is satisfactory for analysis on mass spectrometry.

The blank, standard solution and spiked-blank samples with concentrations of EG at $0.2 \mathrm{mg} / \mathrm{kg}$ were analyzed using the optimized method. The chromatograms showed that the blank sample shows no signal at the retention time of the analyte. The spiked-blank sample has a signal at a retention time of 3.63 minutes that coincides with the retention time of the standard solution (3.62 minutes), with a difference of not more than $5 \%$.

For mass spectrometry, the ratio of ions is the criterion to confirm the presence of an analyte. The ion ratio is the percentage of the lower signal ions divided by the higher signal ions of the same precursor ion. To calculate ion ratio, standard solution and spiked-blank samples were analyzed, then compare the obtained ion ratio. The result showed that the ion ratio of the standard solution and the spiked sample is $8.12 \%$ and $5.57 \%$, respectively. The deviation of the spiked sample when compared with results of standard solution varied $4.06-12.18 \%$, in the range of $\pm 50 \%$, conformed European regulations (EC/657/2002) [8]. Therefore, the method had high specificity, suitable for EG analysis.

Table 2. Ion ratio of Ethylene glycol analyzed by LC-MS/MS

\begin{tabular}{ccccc}
\hline Analyte & $\begin{array}{c}\text { Ion ratio in } \\
\text { standard solution }\end{array}$ & $\begin{array}{c}\text { Permitted } \\
\text { tolerances }\end{array}$ & $\begin{array}{c}\text { Maximum permitted } \\
\text { tolerances }\end{array}$ & $\begin{array}{c}\text { Ion ratio in } \\
\text { spike sample }\end{array}$ \\
\hline $\boldsymbol{E} \boldsymbol{G}$ & $8.12 \%$ & $\pm 50 \%$ & $4.06 \%-12.18 \%$ & $5.57 \%$ \\
\hline
\end{tabular}

\subsubsection{Linearity}

Spiking standard solution into the blank and solvent at concentrations of $1-20 \mathrm{mg} / \mathrm{L}$, do the same with the sample and analyzed by LC-MS/MS method to determine the linearity of the method. The standard curve representing the dependence between Speak of standard/Speak of internal standard and the corresponding concentration was made by the instrument's software. The calibration curve was presented in Figure 3.

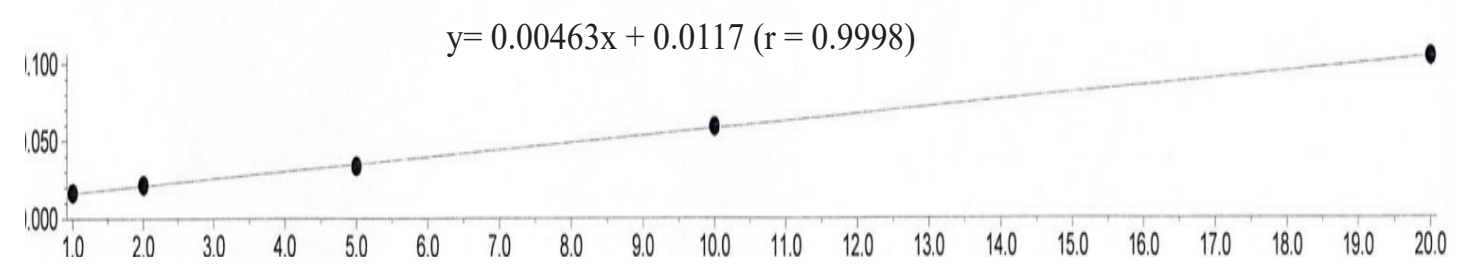

Figure 3. Ethylene glycol calibration curve

The result showed good linearity with the variance coefficient being higher than 0.99 with a bias of $<15 \%$ for all values. The slope of the calibration curve in matrix and solvent was 0.157 and 0.00463 , respectively. 


\subsubsection{Limit of detection - Limit of quantification}

The analysis of EG was repeated six times to determine the $\mathrm{S} / \mathrm{N}$ ratio. The of detection is the concentration at which $\mathrm{S} / \mathrm{N} \geq 3$. The limit of quantification is the limit at which $\mathrm{S} / \mathrm{N}=10$ or $\mathrm{LOQ}=3.3 \times$ LOD $($ Figure 4$)$.

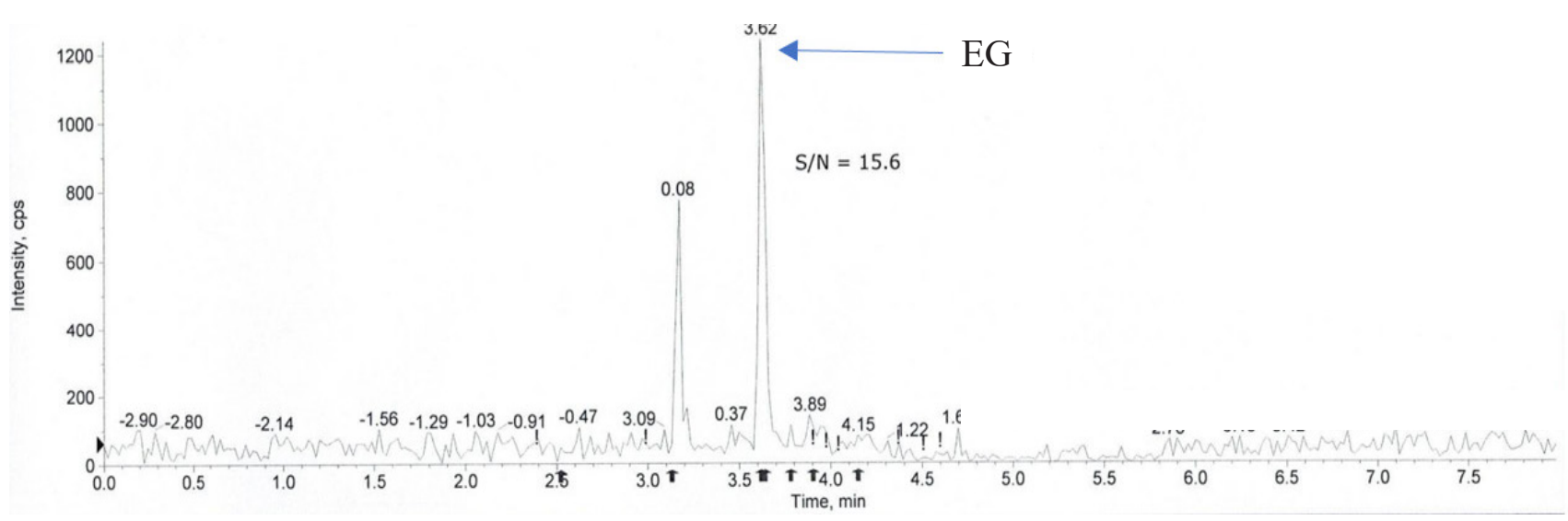

Figure 4. Ethylene glycol at detection level $0.1 \mathrm{mg} / \mathrm{kg}$

\subsubsection{Precision and recovery}

Precision and recovery are two important factors in evaluating the effectiveness of an analytical method. We performed analysis of standard addition on the real sample to conduct the simultaneous determination of these two factors, and evaluate the repeatability and recovery of EG at three concentration levels $0.1,0.2$, and $0.5 \mathrm{mg} / \mathrm{kg}, \mathrm{n}=6$. For reproductivity evaluation, two staff performed the same analysis on the same concentration $0.2 \mathrm{mg} / \mathrm{kg}$, six times for each. The results of the recovery and precision calculations were presented in Table 3.

Table 3. Precision and recovery

\begin{tabular}{cc}
\hline Parameters & Values \\
\hline Repeatability (RSDr) & $3.08-4.41 \%$ \\
Reproductivity (RSDR) & $4.21 \%$ \\
Recovery range & $91.1-102.0 \%$ \\
\hline
\end{tabular}

\subsubsection{Uncertainty}

The measurement uncertainty $(\mathrm{U})$ was evaluated based on recovery and reproducibility according to "Guidelines on Estimation of Uncertainty of Results" (CAC/GL 59-2006) [9] and ISO 21748:2004 "Guidance for the Use of repeatability, reproductivity and trueness estimates in measurement uncertainty estimation" [10]. The result showed that measurement uncertainty of the method was $13.3 \%$.

\subsection{Application for real samples}

The procedure, after being optimized and validated, was applied for the analysis of 20 animal feed samples, each sample was prepared in duplicate. Animal feeds were collected from a variety of brands and non-brands in Hanoi, such as supermarkets, local stores, vet clinics, and pet stores. The supermarket and vet clinic only sold the brands. However, the local and pet store not only had the brands, but also the non-brands. In Figure 5, number of samples purchased from each source was depicted. While supermarkets and vet clinics only sole brand products, local stores and pet stores sole both brand and non-brand feeds. 


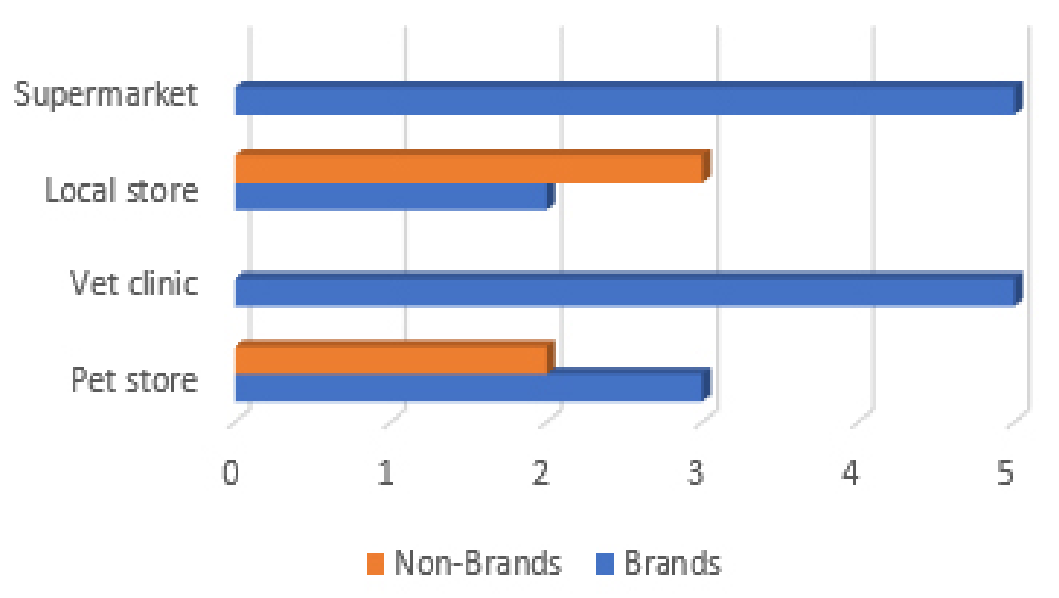

Figure 5. The total number of investigated samples for each type of brand and type of location

Each sample was homogenized before analysis. Among 20 samples, five samples which detected with EG at different concentrations of 3.0, 3.5, 5.2, 8.9, and $10.0 \mathrm{mg} / \mathrm{kg}$, were all non-brands. It can be concluded that brand animal feeds are well controlled for safety, and products without labels are not. According to United States Agency for Toxic Substances and Disease Registry (ATSDR), the chronic oral Minimal Risk Levels (MRLs) for EG is $0.8 \mathrm{mg} / \mathrm{kg} /$ day has been derived for acute-duration oral exposure ( $\leq 14$ days) [11]. However, based on the same endpoint as Environmental Protection Agency's reference dose, the MRL is $2.0 \mathrm{mg} / \mathrm{kg} / \mathrm{day}$ [12]. It means that, the MRL is still not unified globally. On the other hand, although there are many potential risks to animal health, up to now, Vietnam has not had regulations related to the allowable levels of EG in animal feed. The method has been designated as a method for state management in the field of animal feed safety. The results of the study contribute to providing data for Vietnamese regulatory agencies

\subsection{Limitation}

The method uses PG as a surrogate, in both sample processing and analysis simultaneously in the instrument. This could not be as accurate as using the isotope internal standard of EG but can be used alternatively instead.

\section{CONCLUSION}

So far, a sensitive method for analysis of EG in animal feed has been reported. The method was validated and met the AOAC International requirements for selectivity, specificity with a good linear range of $1 \div 20 \mathrm{mg} / \mathrm{kg}$. LOD and LOQ were 0.03 and $0.1 \mathrm{mg} / \mathrm{kg}$. The recoveries of EG were from 91.1 to $102.0 \%$ and the relative standard deviations were within the range of $3.08 \div 4.41 \%$. The measurement uncertainty of the method for animal feed was $13.3 \%$. The method is qualified to conduct interlaboratory validation. It can become a standard method that will contributing to safety confirmation of EG-containing products including food and feed on the market.

\section{REFERENCES}

[1]. United States Centers for Disease Control and Prevention, "Ethylene Glycol". Online. Address: https://www.cdc.gov/niosh/topics/ethylene-glycol/default.html [Accessed 11/11/2021].

[2]. United States Centers for Disease Control and Prevention, "Ethylene Glycol: Systemic". Online. Address:https://www.cdc.gov/niosh/ershdb/emergencyresponsecard_29750031.html[Accessed 11/11/2021).

[3]. Medscape, "Ethylene Glycol Toxicity: Practice Essentials, Pathophysiology, Etiology", [Online]. Address: https://emedicine.medscape.com/article/814701-overview [Accessed on 11/11/2021].

[4]. K. Aarstad, O. Dale, O. Aakervik, S. Øvrebø, and K. Zahlsen, "A Rapid Gas Chromatographic Method for Determination of Ethylene Glycol in Serum and Urine," Journal of Analytical Toxicology, vol. 17, no. 4, pp. 218-221, 1993. 
[5]. M. Dziadosz, "Direct analysis of ethylene glycol in human serum on the basis of analyte adduct formation and liquid chromatography-tandem mass spectrometry," Journal of Chromatography B, Analytical Technologies in the Biomedical and Life Sciences, vol. 1072, pp. 100-104, 2018.

[6]. B. N. Tran, R. Okoniewski, A. Bucciferro, R. Jansing, and K. M. Aldous, "Determination of trace amounts of ethylene glycol and its analogs in water matrixes by liquid chromatography/tandem mass spectrometry," Journal of AOAC International, vol. 97, no. 1, pp. 232-237, 2014.

[7]. AOAC International "AOAC Appendix F", [Online]. Address: http://www.eoma.aoac.org/app_f.pdf [Accessed on 22/11/2021].

[8]. European Union, “2002/657/EC: Commission Decision of 12 August 2002 implementing Council Directive 96/23/EC concerning the performance of analytical methods and the interpretation of results (Text with EEA relevance) (notified under document number C(2002) 3044) - Publications Office of the EU." [Online]. Address: https://op.europa.eu/en/publication-detail/-/publication/ed928116-a9554a84-b10a-cf7a82bad858/language-en [Accessed on 25/11/2021].

[9]. Food and Agriculture Organization, "Guidelines on Estimation of Uncertainty of Results", [Online]. Address: www.fao.org/input/download/standards/13622/cxg_084e.pdf [Accessed on 25/11/2021].

[10]. International Organization for Standardization, “ISO/TS 21748:2004". [Online]. Address: https:// www. iso.org/cms/render/live/en/sites/isoorg/contents/data/standard/03/46/34686.html [Accessed on 25/11/ 2021].

[11]. United States Centers for Disease Control and Prevention, “Toxic guideline" [Online]. Address: https:// www.atsdr.cdc.gov/toxguides/toxguide-96.pdf [Accessed on 25/11/2021].

[12]. C.-H. S. J. Chou and H. R. Pohl, "Health effects classification and its role in the derivation of minimal risk levels: Renal effects," Regulatory Toxicology and Pharmacology: RTP, vol. 42, no. 2, pp. 202208, 2005.

\title{
Phân tích ethylene glycol trong thức ăn chăn nuôi bằng sắc ký lỏng ion hóa phun điện tử ghép nối khối phổ hai lần
}

\author{
Nguyễn Thị Hồng Ngọc ${ }^{1}$, Nguyễn Hà Thanh ${ }^{1}$, Bùi Cao Tiến ${ }^{1}$, \\ Trần Cao Sơn ${ }^{1}$, Đinh Minh Nhật ${ }^{2}$, Phạm Thị Thanh Hà \\ ${ }^{1}$ Viện Kiểm nghiệm an toàn vệ sinh thực phẩm quốc gia, Hà Nội, Việt Nam \\ ${ }^{2}$ Trưòng Đại học Dược Hà Nội, Hà Nội, Việt Nam
}

\section{Tóm tắt}

Phương pháp xác định ethylene glycol trong thức ăn chăn nuôi bằng sắc ký lỏng kết hợp với ion hóa phun điện tử ghép nối khối phổ hai lần (LC-ESI-MS/MS) đã được xây dựng và thẩm định. Phương pháp này được thực hiện với cột $\mathrm{C} 18(150 \mathrm{~mm} \times 4,6 \mathrm{~mm}, 3,5 \mu \mathrm{m})$, pha động gradient bao gồm acid formic $0,1 \%$ và acetonitrile. Ethylene glycol và chất chuẩn đồng hành (propylene glycol) được chiết xuất bằng nước ở nhiệt độ phòng, tạo dẫn xuất bằng benzoyl chloride trong môi trường kiềm và được phân tích bằng LC-ESI-MS/MS. Kết quả thẩm định cho thấy phương pháp này có độ đặc hiệu và độ chọn lọc cao với giới hạn phát hiện $0,1 \mathrm{mg} / \mathrm{kg}$, khoảng tuyến tính $1-20 \mu \mathrm{g} / \mathrm{mL}$, độ lặp lại $3,08-4,41 \%$, và độ thu hồi 91,1 - 102,0 \%, đáp ứng các yêu cầu của AOAC. Phương pháp đã được áp dụng để phân tích một số thức ăn chăn nuôi phân phối trên thị trường.

Keywords: ethylene glycol, animal feed, LC-ESI-MS/MS. 